\title{
Meningkatkan Hasil Belajar Dengan Penggunaan Media Peta Pada Materi Pengetahuan Dasar Pemetaan Siswa Kelas X IPS-2 SMAN 1 Wangi-Wangi
}

\author{
Chindy Citra Dewi ${ }^{1}$, Surdin $^{2}$, La Ode Amaluddin ${ }^{3}$, Rahma Musyawarah ${ }^{4}$ \\ 1234 PROGRAM STUDI GEOGRAFI / UNIVERSITAS HALU OLEO \\ Email : chindycitradewi98@gmail.com
}

(Received: Agustus 2019; Reviewed: Agustus 2019; Accepted: September 2019; Published: Oktober 2019)

\begin{abstract}
SMAN 1 Wangi-Wangi is one of the schools in Wakatobi Regency which is the location of research because the learning outcomes are still low. The purpose of this study is (1) To find out student learning activities by using map media on basic knowledge mapping materials. (2) To find out the teaching activities of teachers by using map media on basic knowledge mapping materials. (3) To find out the geography learning outcomes of students of cl ass X IPS-2 of SMA Negeri 1 Wangi-Wangi by using map media on mapping basic knowledge material. This research is a classroom action research (CAR) and the data of this study using activity observation sheets that contain student learning activities and teacher teaching activities, while to obtain student geography learning outcomes by conducting tests as a research method. From the results of the study showed that: (1) student learning activities obtained an average score of 3.5 which is categorized as good. (2) teacher teaching activities obtained an average score of 3.4 which is categorized as good. (3) the geography learning outcomes of students of class X IPS-2 SMAN 1 obtained an average score of 79, with $81 \%$ completeness or there were 26 students from 32 students with a value of $\geq 70$ according to the KKM of geography subjects. So, it can be concluded that after the implementation of cycle 1 and cycle 2 by using map media on student learning activities, teacher teaching activities, and student learning outcomes have increased.
\end{abstract}

Keywords : Learning Outcomes, Map Media, Basic Knowledge of Mapping, X IPS2 SMAN 1 Wangi-Wangi

ABSTRAK

SMAN 1 Wangi-Wangi adalah salah satu sekolah di Kabupaten Wakatobi yang menjadi lokasi penelitian karena hasil belajarnya yang masih rendah. Tujuan dari penelitian ini adalah: (1) Untuk mengetahui aktivitas belajar siswa dengan penggunaan media peta pada materi pengetahuan dasar pemetaan. (2) Untuk mengetahui aktivitas mengajar guru dengan penggunaan media peta pada materi pengetahuan dasar pemetaan. (3) Untuk mengetahui hasil belajar geografi siswa kelas X IPS-2 SMA Negeri 1 Wangi-Wangi dengan penggunan media peta pada materi pengetahuan dasar pemetaan. Penelitian ini merupakan penelitian tindakan kelas (PTK) dan data dalam penelitian ini menggunakan lembar observasi 
aktivitas yang memuat tentang aktivitas belajar siswa dan aktivitas mengajar guru, sedangkan untuk mendapatkan hasil belajar geografi siswa dengan melakukan tes sebagai metode penelitian. Dari hasil penelitian menunjukkan bahwa : (1) aktivitas belajar siswa diperoleh skor rata-rata 3,5 yang berkategorikan baik (2) aktivitas mengajar guru diperoleh skor rata-rata 3,4 yang berkategorikan baik (3) hasil belajar geografi siswa kelas X IPS-2 SMAN 1 diperoleh skor rata-rata 79, dengan ketuntasan $81 \%$ atau terdapat 26 siswa dari 32 siswa dengan nilai $\geq 70$ sesuai KKM mata pelajaran geografi. Jadi, dapat disimpulkan bahwa setelah keterlaksanaan siklus 1 dan siklus 2 dengan menggunakan media peta pada aktivitas belajar siswa, aktivitas mengajar guru, dan hasil belajar siswa mengalami peningkatan.

Kata Kunci : Hasil Belajar, Media Peta, Pengetahuan Dasar Pemetaan, X IPS-2 SMAN 1 Wangi-Wangi

\section{PENDAHULUAN}

Kemajuan di bidang teknologi pendidikan menuntut dunia pendidikan untuk menggunakan berbagai media dalam pembelajaran, dapat dikatakan bahwa kegiatan pembelajaran telah bergerak dan berkembang, penyampaian materi secara konvensial dengan metode ceramah perlahan mulai diganti dengan menerapkan pembelajaran yang lebih mengedepankan peran dan partisipasi pembelajar atau peserta didik dan pemanfaatan media pembelajaran. Sesuai dengan pendapat Rosenberg dalam Soedibyo (2011), dengan berkembangnya penggunaan teknologi informasi dan komunikasi maka ada lima pergeseran dalam proses pembelajaran, yaitu : (1) dari pelatihan ke penampilan (2) dari ruang kelas ke dimana dan kapan saja (3) dari kertas ke "on line" atau saluran (4) dari fasilitas jaringan kerja (5) dari waktu siklus ke waktu nyala.

Media pembelajaran menurut Azhar (2011) adalah alat bantu proses belajar, baik di dalam maupun di luar kelas, lebih lanjut dijelaskan bahwa media pembelajaran adalah komponen sumber belajar atau wahana fisik yang mengandung materi instruksional di lingkungan siswa yang dapat merangsang siswa untuk belajar.

Dalam bentuk komunikasi pembelajaran manapun sangat dibutuhkan peran media untuk lebih meningkatkan tingkat keefektifan pencapaian tujuan/kompetensi. Artinya, proses pembelajaran tersebut akan terjadi apabila ada komunikasi antara penerima pesan dengan sumber/penyalur pesan lewat media tersebut (Prasetya, 2015).

Untuk mencapai tujuan mata pelajaran geografi, tak cukup pendekatan, strategi, model dan metode pembelajaran yang digunakan, namun kehadiran media pembelajaran memiliki peran penting untuk ikut mewujudkan tercapainya tujuan mata pelajaran geografi. Sesuai dengan pendapat Hamalik (2006) bahwa penggunaan media pembelajaran pada tahap orientasi pembelajaran akan sangat membantu keefektifan proses pembelajaran.

Memanfaatkan peta sesuai dengan materi pengetahuan dasar pemetaan pada kelas X, merujuk pada standar isi mata pelajaran geografi yang telah ditetapkan oleh Badan Standar Nasional Pendidikan (BSNP 2006), tujuan mata pelajaran geografi adalah :

1. Memahami pola spasial, lingkungan dan kewilayahan serta proses yang berkaitan

2. Menguasai keterampilan dasar dalam memperoleh data dan informasi, mengkomunikasikan dan menerapkan pengetahuan geografi 
3. Menampilkan perilaku peduli terhadap lingkungan hidup dan memanfaatkan sumber daya alam secara arif serta memiliki toleransi terhadap keragaman budaya masyarakat.

Penulis ingin memberikan pengalaman belajar yang berbeda dan menyenangkan kepada peserta didik kelas X IPS-2 SMAN 1 Wangi-Wangi pada materi pengetahuan dasar pemetan, dimana peserta didik akan berpartisipasi aktif dan terlibat langsung dengan penggunaan media dalam kegiatan belajar mengajar, karena penggunaan media peta akan melibatkan aktivitas siswa secara langsung. Dalam kegiatan nanti, peserta didik akan melakukan kegiatan praktikum dalam kelompok-kelompok kecil untuk menggambar peta menggunakan media peta dan kertas kalkir.

Berdasarkan hasil wawancara dengan guru, KKM mata pelajaran geografi kelas $\mathrm{X}$ di SMA Negeri 1 Wangi-Wangi adalah 70, dan pencapaian untuk hasil belajar pada kelas X IPS-2 masih terbilang rendah, sehingga untuk dapat memenuhi KKM yang telah ditetapkan, guru melakukan remedial atau perbaikan nilai sebagai penunjang hasil belajar peserta didik yang sebelumnya agar dapat mencapai KKM. Menurut guru mata pelajaran, diduga salah satu faktor rendahnya hasil belajar siswa kelas X IPS-2 karena kurangnya motivasi dan antusias peserta didik.

Harapan dari penggunaa peta sebagai media pembelajaran agar dapat menumbuhkan antusias peserta didik dan mengantarkan pemahaman peserta didik pada pengetahuan konkret mengenai unsur-unsur dalam peta (skala, legenda, orientasi, dll), meningkatkan keterampilan motorik seperti menggambar, menulis, konsentrasi, menumbuhkan sikap toleransi, kerjasama dan bertanggungjawab (bekerja secara berkelompok) serta diharapkan dengan penggunaan media pembelajaran dapat meningkatkan hasil belajar peserta didik khususnya siswa kelas X IPS-2 SMAN 1 Wangi-Wangi.

Berdasarkan latar belakang di atas, maka peneliti terinspirasi untuk melakukan penelitian dengan judul "Meningkatkan Hasil Belajar Dengan Penggunaan Media Peta Pada Materi Pengetahuan Dasar Pemetaan Siswa Kelas X IPS-2 SMAN 1 Wangi-Wangi."

\section{METODE}

\section{Jenis Penelitian}

Jenis penelitian adalah Penelitian Tindakan Kelas (PTK) yaitu suatu penelitian yang dilakukan dengan menggunakan media peta pada materi pengetahuan dasar pemetaan yang bertujuan untuk mengetahui peningkatan aktivitas belajar siswa dan aktivitas mengajar guru serta mengetahui peningkatan hasil belajar siswa.

\section{Tempat dan Waktu Penelitian}

Penelitian ini dilakukan di SMA Negeri 1 Wangi-Wangi, Jln. Lebe Umara No.1, Kelurahan Pongo, Kecamatan Wangi-Wangi, Kabupaten Wakatobi, Provinsi Sulawesi Tenggara.

\section{Subjek Penelitian}

Subjek penelitian terdiri dari guru dan siswa kelas X IPS-2 SMA Negeri 1 Wangi-Wangi yang berjumlah 32 orang siswa, dengan jumlah siswa laki-laki sebanyak 20 orang dan siswa perempuan sebanyak 12 orang. 


\section{Teknik Pengumpulan Data}

Teknik pengumpulan data dalam penelitian ini adalah (1) data mengenai aktivitas siswa diambil dengan menggunakan lembar observasi dengan cara memberikan skor pada aspek aktivitas yang dilakukan untuk siswa sesuai dengan kriteria yang telah ditentukan; (2) data mengenai hasil belajar geografi diambil dengan menggunakan tes hasil belajar (tes siklus) dengan bentuk tes berupa tes essay yang mencakup semua indikator pembelajaran pada siklus I serta siklus II.

\section{Teknik Analisis Data}

Data dalam penelitian ini dianalisis dengan menggunakan statistik deskriptif, baik secara kualitatif maupun kuantitatif. Analisis deskriptif kualitatif digunakan untuk memberikan penjelasan mengenai aktivitas belajar siswa dan aktivitas mengajar guru selama proses pembelajaran berlangsung. Analisis deskriptif kuantitatif digunakan untuk menyajikan angka-angka (skor) persentase aktivitas guru dalam mengelola pembelajaran, persentase aktivitas belajar siswa dan persentase ketuntasan hasil belajar siswa. Adapun langkah-langkah yang digunakan dalam menganalisis data tersebut dapat dikembangkan sebagai berikut:

a) Menentukan hasil belajar siswa:

$X_{i}=\frac{S p i}{S m} \times 100$

(Usman dan Setiawati, 2001)

Keterangan:

$\mathrm{Xi}=$ Nilai yang diperoleh siswa ke- $\mathrm{i}$

Spi = Skor yang diperoleh siswa ke-i

$\mathrm{Sm}=$ Skor maksimum yang mungkin dicapai (skor ideal)

b) Menentukan tingkat pencapaian ketuntasan belajar : (Sudjana, 2002)

$\%$ Tuntas $=\frac{\sum T B}{N} X 100 \%$

Keterangan:

$\sum T B=$ Jumlah Siswa yang tuntas belajar

$\mathrm{N}=$ Jumlah Siswa secara keseluruhan

Nilai Klasikal $=\frac{\text { Nilai } \text { rata }- \text { rat }}{\text { nilai } \text { ideal }} \times 100 \%$

c) Menghitung nilai rata-rata hasil belajar siswa dengan rumus:

$\bar{X}=\frac{\sum_{i=1}^{n} X_{i}}{n}($ Sudjana, 2002)

Keterangan:

$\bar{X}=$ nilai rata-rata yang diperoleh siswa

$\mathrm{n} \quad=$ jumlah siswa secara keseluruhan

$\mathrm{Xi}=$ nilai yang diperoleh tiap siswa

d) Menghitung keberhasilan aktivitas mengajar guru menggunakan rumus:

$\% \mathrm{KAMG}=\frac{\text { Jumlah skor perolehan siswa }}{\text { Jumlah skor maksimum }} \times 100 \%$

Keterangan:

$\mathrm{KAMG}=$ Keberhasilan aktivitas mengajar guru

(Mulyasa, 2003)

e) Keberhasilan aktivitas belajar siswa :

$\% \mathrm{KABS}=\frac{\text { Jumlah skor perolehan }}{\text { Jumlah skor maksimum }} \times 100 \%$ 
Keterangan:

KABS = Keberhasilan aktivitas belajar siswa

(Mulyasa, 2003)

\section{HASIL DAN PEMBAHASAN}

\section{Hasil}

\section{Pelaksanaan Tindakan siklus I}

\section{Perencanaan}

Hal-hal yang dilakukan pada tahap perencanaan ini adalah: (1) menyiapkan RPP sesuai dengan media peta untuk pertemuan 1 dan peretmuan 2 (2) menyiapkan lembar kerja siswa (LKS 01 dan LKS 02 (3) mempersiapkan sumber, bahan, dan alat bantu yang dibutuhkan (4) menyiapkan lembar observasi pembelajaran, format observasi siswa dan guru (5) menyusun soal evaluasi tes hasil belajar siswa berupa essay.

\section{Pelaksanaan Tindakan}

Pelaksanaan tindakan pada siklus I dilaksanakan dalam dua kali pertemuan sesuai dengan RPP.

\section{Aktivitas Siswa Pertemuan 1 dan 2 pada Siklus I}

Gambaran rata-rata aktivitas siswa dengan menggunakan media peta pada siklus I untuk setiap aspek aktivitas yang dinilai dapat dilihat pada gambar 1 berikut:

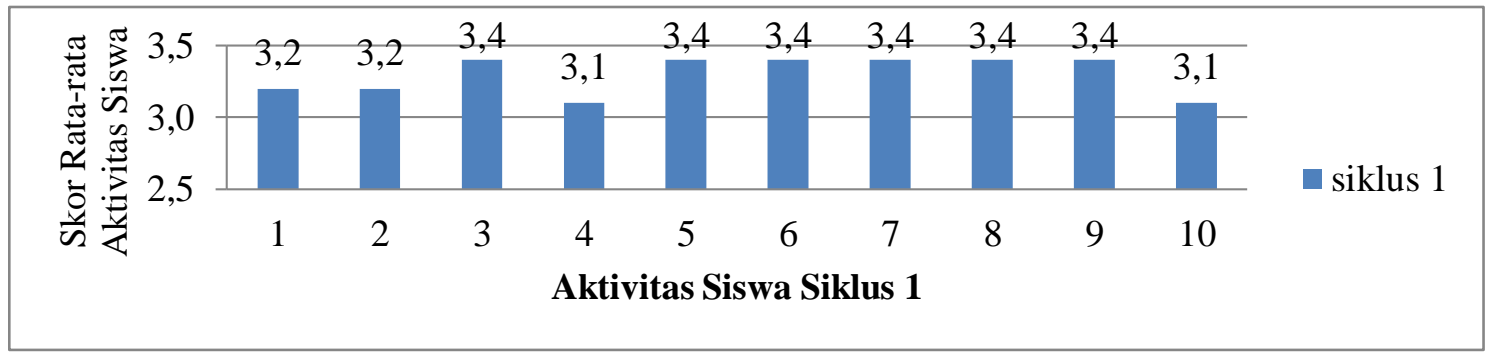

Gambar 1. Grafik Skor Rata-Rata Aktivitas Siswa Pada Siklus I (Analisis Data Primer, 2019).

Keterangan:

1. Langsung menyesuaikan diri dengan kelompok yang sudah dibagikan guru

2. Mengamati penjelasan guru dengan tenang;

3. Aktif dan antusias dalam bertanya

4. Tertib dalam berdiskusi dan bekerja sama dalam kelompok;

5. Menyelesaikan hasil diskusi tepat waktu

6. Mempresentasikan hasil diskusi dengan bahasa yang santun dan jelas;

7. Menyimak dan menanggapi hasil diskusi kelompok lain; 
8. Menyimak evaluasi dan penguatan yang diberikan guru;

9. Berpartisipasi dalam panrikan kesimpulan seluruh rangkaian materi pembelajaran;

10. Bertanya terkait materi selanjutnya sebelum pelajaran ditutup.

Berdasarkan gambar di atas tentang hasil observasi aktivitas siswa diperoleh gambaran bahwa hasil aktivitas siswa tersebut sudah memenuhi kriteria ketuntasan minimal yaitu 3.0 karena rata-rata aktivitas memperoleh nilai 3,3 yang berkategorikan baik.

Rata-rata aktivitas siswa selama pembelajaran pada siklus I pertemuan 1 dan 2 dapat dilihat pada gambar berikut :

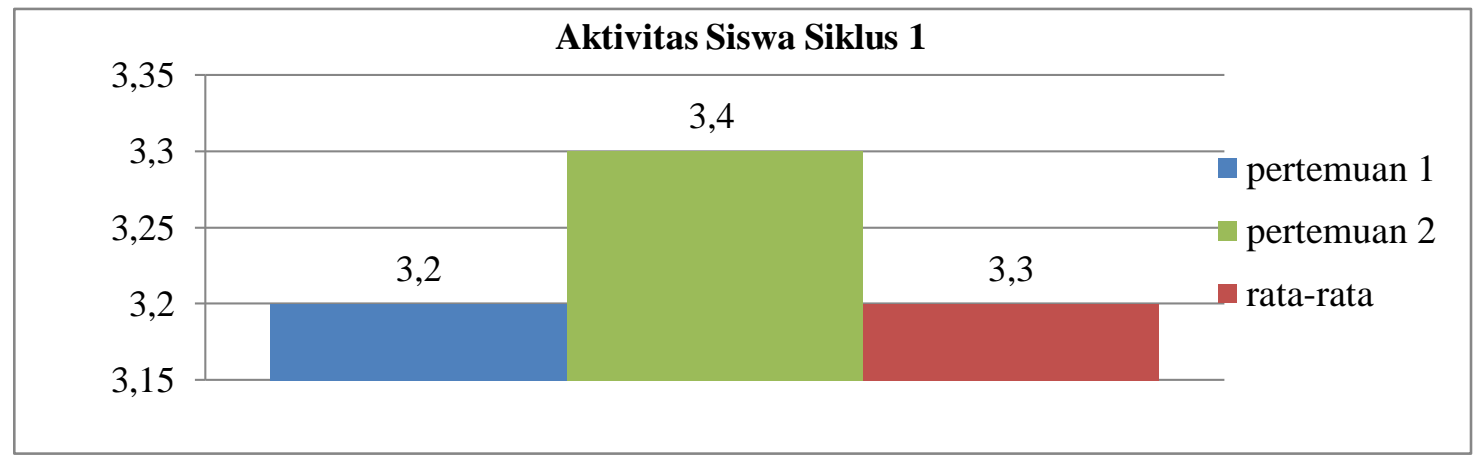

Gambar 2. Grafik Skor Rata-Rata Aktivitas Siswa Siklus I Pertemuan 1 dan 2

(Analisis Data Primer, 2019)

Berdasarkan gambar 2 di atas, dapat dikatakan bahwa aktivitas siswa di siklus I sudah tergolong baik hal itu dikarenakan sudah mencapai batas ketuntasan yang di tetapkan yaitu $\geq 3,0$.

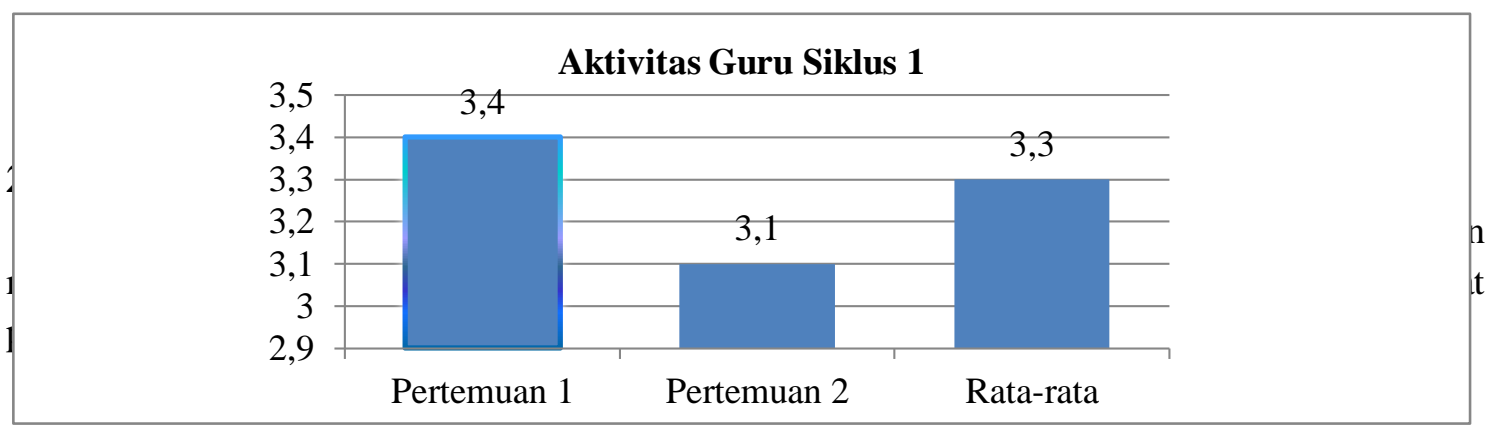

Gambar 3. Grafik Skor Rata-Rata Aktivitas Guru Siklus I (Analisis Data Primer, 2019)

Berdasarkan gambar 3 di atas menunjukkan bahwa, aktivitas guru sudah memenuhi kriteria ketuntasan minimal yaitu 3,0 karena aktivitas guru sudah mencapai skor rata-rata 3,3 yang berkategorikan baik.

\section{Hasil Belajar Siswa Pertemuan I dan II Siklus I}

Untuk hasil belajar siswa pada siklus I diperoleh melalui tes yang diberikan di akhir pertemuan siklus dan dapat dilihat melalui tabel 1 berikut: 
Tabel 1. Data Analisis Ketuntasan Hasil Belajar Siswa Pada Siklus I

\begin{tabular}{lccc}
\hline Skor & Jumlah Siswa & Perssentase & Ketuntasan Belajar \\
\hline $0-69$ & 13 & $41 \%$ & belum tuntas \\
$72-100$ & 19 & $59 \%$ & sudah tuntas \\
\hline Jumlah & 32 & $100 \%$ & \\
\hline & Keterangan \\
\hline Tuntas & 19 siswa \\
\hline Tidak tuntas & 13 siswa \\
\hline Nilai rata-rata & 71 \\
\hline Nilai maksimum & 93 \\
\hline Nilai minimum & \multicolumn{3}{|}{47} \\
\hline Persentase ketuntasan & $59 \%$ \\
\hline
\end{tabular}

Sumber: Analisis Data Primer, 2019

Data di atas menunjukan bahwa hasil belajar siswa pada siklus I menunjukkan bahwa yang memperoleh skor antara 0-69 berjumlah 13 siswa dengan persentase $41 \%$, sedangkan siswa yang memperoleh skor 70-100 berjumlah 19 siswa dengan persentase $59 \%$, namun hasil tersebut belum memenuhi indikator ketuntasan keberhasilan yaitu sebesar $80 \%$ siswa yang mencapai ketuntasan belajar belum mencapai indikator ketuntasan keberhasilan yaitu $80 \%$ siswa yang mencapai ketuntasan hasil belajar. Untuk lebih jelasnya gambaran hasil belajar yang sudah tuntas dan yang belum tuntas siklus I dapat dilihat pada gambar 4 berikut:

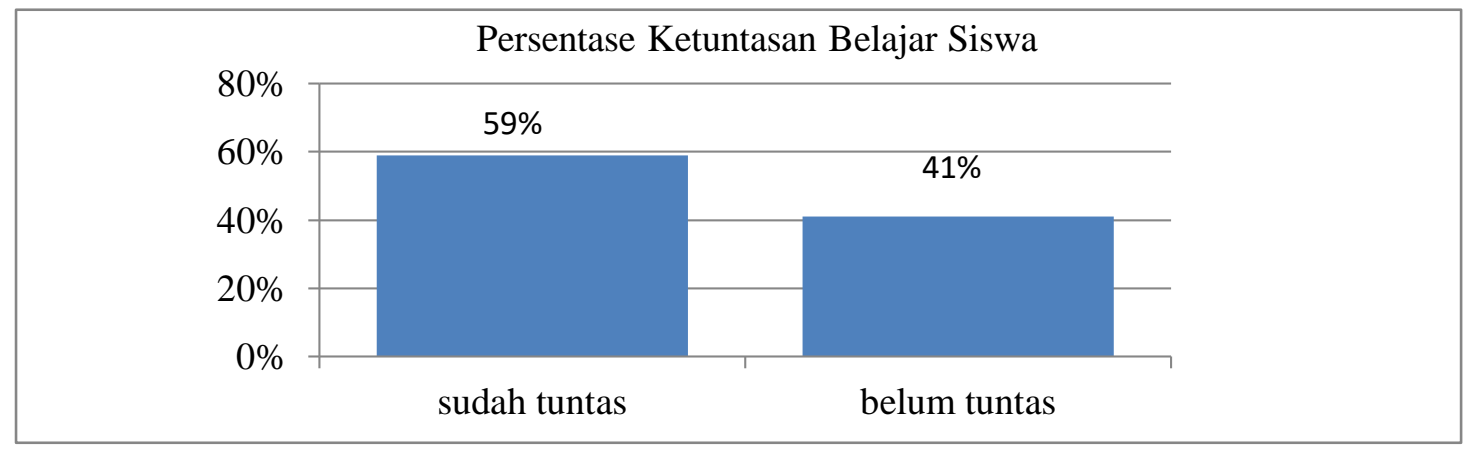

Gambar 4. Persentase Ketuntasan Hasil Belajar Siswa Siklus I (Analisis Data Primer, 2019)

Oleh karena di siklus I hipotesis tindakan penelitian untuk aktivitas belajar siswa dan aktivitas mengajar guru sudah tercapai namun hasil belajar siswa belum tercapai maka perlu dilanjutkan ke siklus II dengan tujuan mencari jawaban atas hipotesis.

\section{Pelaksanaan Tindakan Siklus II Perencanaan}

Setelah mengetahui kekurangan yang terjadi pada siklus I baik yang dilakukan oleh siswa maupun guru, maka pada pembelajaran siklus II guru mencoba memperbaiki kesalahan yang 
dilakukan sebelumnya, sehingga hasil belajar dengan penggunakan media peta dapat tercapai sesuai indikator keberhasilan yaitu $80 \%$.

\section{Pelaksanaan Tindakan}

Pelaksanan tindakan pada siklus II dilaksanakan dalam dua kali pertemuan sesuai RPP.

\section{Aktivitas Belajar Siswa Pertemuan 1 dan 2 Pada Siklus II}

Gambaran rata-rata aktivitas siswa dengan menggunakan media pembelajaran petapada siklus II untuk setiap aspek aktivitas yang dinilai dalam dua pertemuan dapat dilihat pada gambar 5 berikut:

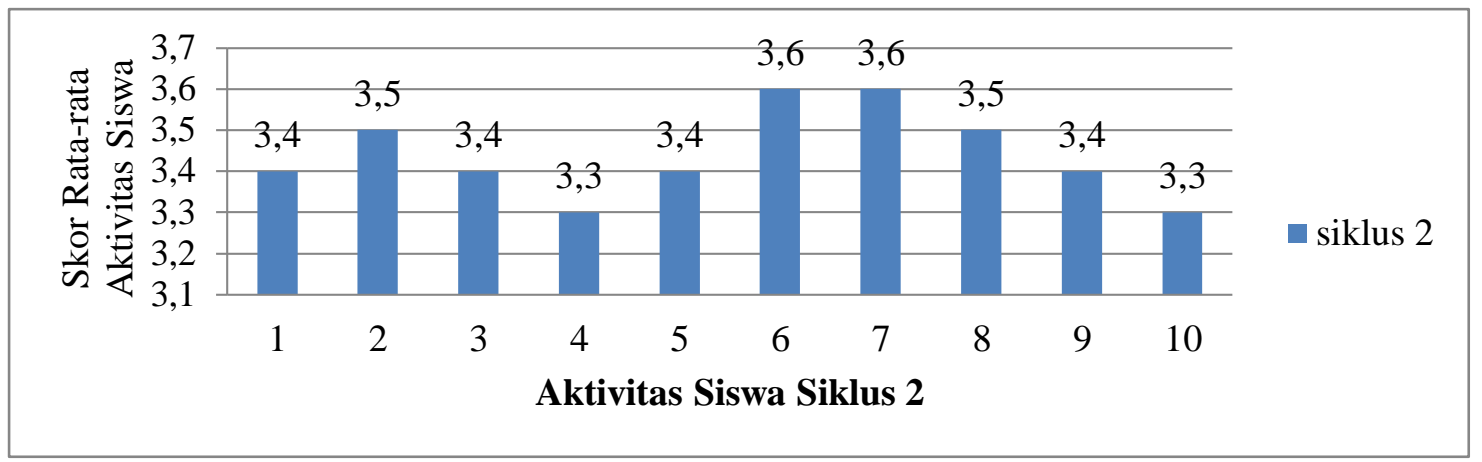

Gambar 5. Grafik Skor Rata-Rata Aktivitas Siswa Pada Siklus II

(Analisis Data Primer, 2019)

Keterangan:

1. Langsung menyesuaikan diri dengan kelompok yang sudah dibagikan guru;

2. Mengamati penjelasan guru dengan tenang;

3. Aktif dan antusias dalam bertanya

4. Tertib dalam berdiskusi dan bekerja sama dalam kelompok;

5. Menyelesaikan hasil diskusi tepat waktu

6. Mempresentasikan hasil diskusi dengan bahasa yang santun dan jelas;

7. Menyimak dan menanggapi hasil diskusi kelompok lain;;

8. Menyimak evaluasi dan penguatan yang diberikan guru

9. Berpartisipasi dalam panrikan kesimpulan seluruh rangkaian materi pembelajaran

10. Bertanya terkait materi selanjutnya sebelum pelajaran ditutup.

Untuk menunjukkaan gambaran rata-rata aktivitas siswa siklus II selama pembelajaran dapat dilihat pada gambar 6 berikut: 


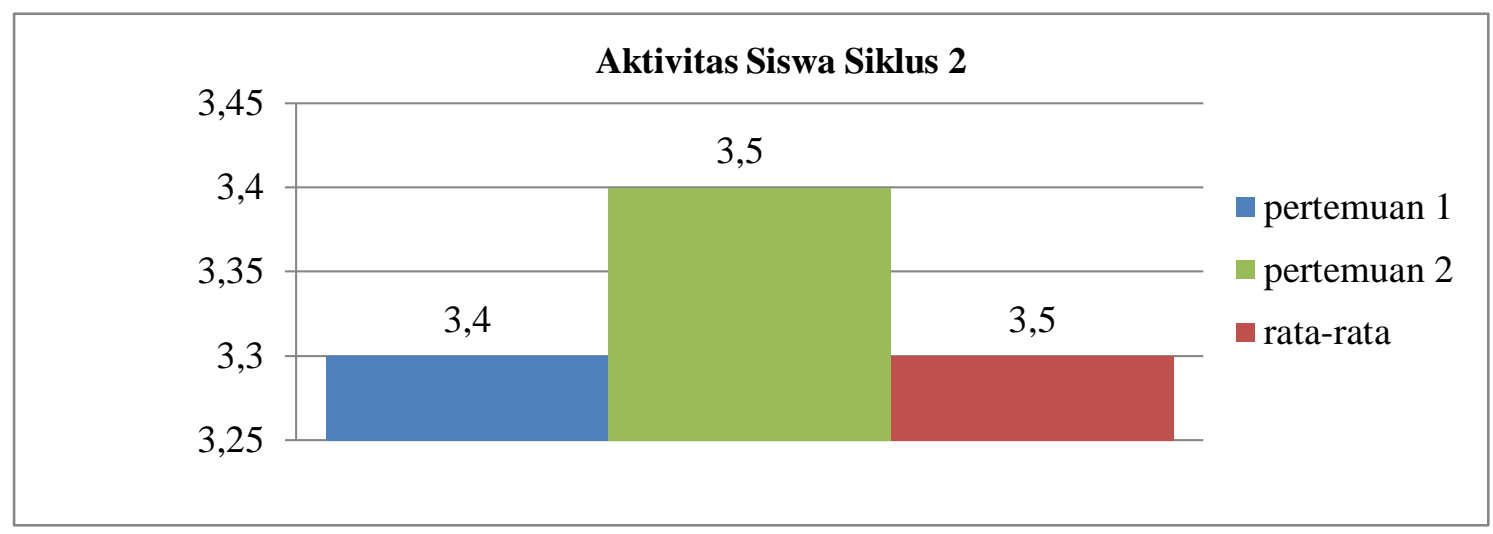

Gambar 6. Grafik Skor Rata-Rata Aktifitas Siswa Siklus II Pertemuan 1 dan 2

(Analisis Data Primer, 2019)

Berdasarkan gambar 6 di atas menunjukan bahwa, aktivitas siswa telah memenuhi kriteria ketuntasan minimal yaitu 3,0 Dimana aktivitas siswa telah mencapai rata-rata 3,5 yang berkategorikan baik. Mengalami peningkatan sebesar 0,2 dari siklus I yaitu 3,2.

\section{Aktivitas Mengajar Guru Pertemuan 1 dan 2 Siklus II}

Gambaran rata-rata aktivitas mengajar guru dalam proses pembelajaran dengan menggunakan media peta pada materi pengetahuan dasar pemetaan yang diperoleh dengan menggunakan lembar observasi aktivitas guru pada siklus II dapat dilihat pada gambar 7 berikut:

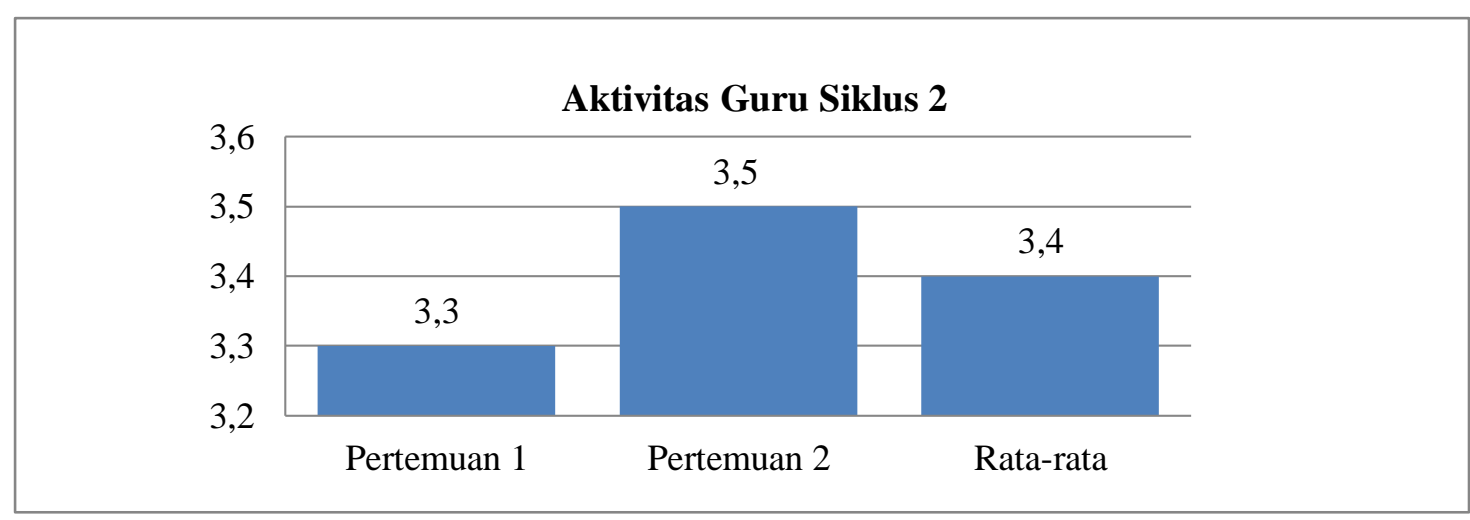

Gambar 7. Grafik Skor Rata-Rata Aktivitas Guru Pada Siklus II (Analisis Data Primer, 2019)

Berdasarkan gambar 7 di atas menunjukkan bahwa . aktivitas guru telah memenuhi kriteria ketuntasan minimal yaitu 3.0. karena aktivitas guru telah mencapai rata-rata 3,4 yang berkategorikan baik. Mengalami peningkatan sebesar 0,1 dari siklus I yaitu 3,3 


\section{Hasil belajar siswa pertemuan 1 dan 2 siklus II}

Untuk hasil belajar siswa pada siklus II diperoleh melalui tes yang diberikan di akhir pertemuan siklus dan dapat dilihat melalui tabel berikut:

Tabel 2. Data Analisis Ketuntasan Hasil Belajar Siswa Pada Siklus II

\begin{tabular}{lccc}
\hline Skor & Jumlah Siswa & Persentase & Ketuntasan Belajar \\
\hline $0-69$ & 6 & $19 \%$ & belum tuntas \\
$70-100$ & 26 & $81 \%$ & sudah tuntas \\
\hline Jumlah & 32 & $100 \%$ & \\
\hline & Keterangan \\
\hline Tuntas & \multicolumn{3}{|}{26 siswa } \\
\hline Tidak tuntas & 7 siswa \\
\hline Nilai rata-rata & 79 \\
\hline Nilai maksimum & \multicolumn{3}{c}{100} \\
\hline Nilai minimum & 40 \\
\hline Persentase \\
ketuntasan
\end{tabular}

Sumber: Analisis Data Primer, 2019

Untuk menunjukkan gambaran hasil belajar siswa yang sudah tuntas dan yang belum tuntas pada siklus II dapat dilihat pada gambar 8 berikut:

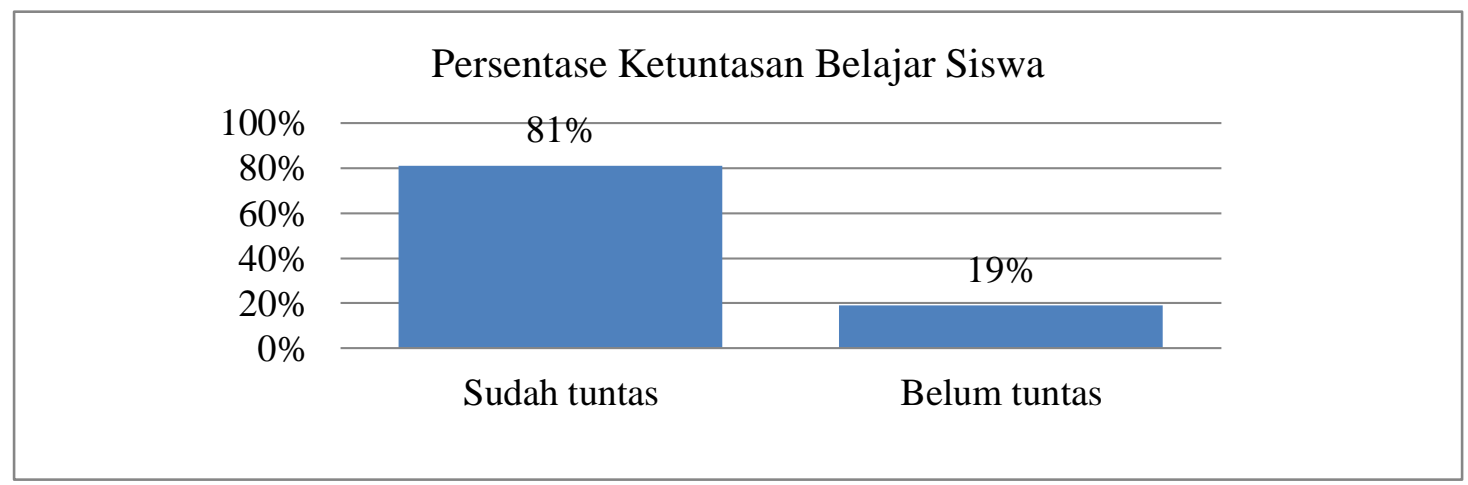

Gambar 8. Persentase Hasil Belajar Siswa Siklus II

Dari tabel 2 dan gambar 8 di atas menunjukan bahwa ketuntasan belajar siswa pada siklus II menunjukkan bahwa hasil belajar siswa pada siklus II yang memperoleh skor antara 0-69 berjumlah 6 siswa dengan persentase 19\%, sedangkan siswa yang memperoleh skor 70-100 berjumlah 26 siswa dengan persentase $81 \%$. Hasil ini sudah lebih baik dibandingkan hasil pada siklus I. Dengan demikian indikator ketuntasan belajar siswa telah tercapai dan itu artinya hasil penelitian ini berhasil karena secara klasikal kriteria ketuntasan yang ditetapkan sebagai 
indikator berhasilnya pembelajaran tersebut sudah memenuhi indikator ketuntasan keberhasilan yaitu sebesar $80 \%$.

\section{Pembahasan}

\section{Aktivitas Belajar Siswa Selama Pembelajaran Berlangsung}

Berdasarkan hasil pengamatan pada dua siklus baik itu siklus I maupun siklus II aktivitas belajar siswa menunjukan peningkatan ke arah yang lebih baik. Hal itu tentu dipengaruhi oleh semangat yang besar oleh siswa dalam mencapai hasil yang optimal.

Sehubungan dengan permasalahan pertama yaitu tentang bagaimana aktivitas belajar siswa di SMAN 1 Wangi-Wangi saat mengikuti pembelajaran dengan memanfaatkan peta sebagai media pembelajaran pada materi pengetahuan dasar pemetaan dapat diuraikan dengan melihat aktivitas belajar siswa pada siklus I dan siklus II yang mempengaruhi hasil belajar.

Berdasarkan pengamatan pada siklus 1 dan siklus II aktivitas belajar siswa menunjukkan peningkatan ke arah yang lebih baik. Hal ini tentu dipengaruhi oleh semangat belajar siswa dan antusias siswa dalam penggunaan media peta dalam pembelajaran sehingga mencapai hasil belajar yang diharapkan. Sesuai dengan pendapat Sudiharjo (1986) bahwa peta memiliki kesan visual yang kuat dan memiliki nilai yang dapat dipercaya. Hal demikian dapat meningkatkan semangat dan antusias belajar siswa.

Pada siklus I berdasarkan hasil analisis deskriptif terhadap aktivitas siswa menunjukkan skor rata-rata sebesar 3,3 yang berkategori baik. Berdasarkan hasil refleksi pada siklus 1 ditemukan beberapa siswa yang belum terlaksana dengan baik, salah satunya siswa kuang aktif dalam bertanya ataupun menjawab pertanyaan dan masih kurang tertib dalam menjaga ketenangan dalam kelas selama pembelajaran. Pada siklus II, dari hasil analisis deskriptif terhadap skor rata-rata aktivitas siswa mengalami peningkatan dengan skor 3,5 yang berkategorikan baik.

\section{Aktivitas Mengajar Guru Selama Pembelajaran Berlangsung}

Berdasarkan hasil analisis deskriptif pada siklus I aktivitas mengajar guru menunjukkan skor rata-rata 3,4 yang berkategorikan baik. Hasil refleksi dari aktivitas guru pada siklus 1 adalah guru masih kurang dalam hal pemberian stimulus dan evaluasi saat pembelajaran kepada siswa. Berdasarkan hasil refleksi tersebut, maka pada siklus II dilakukan tindakan perbaikan. Pada siklus II aktivitas mengajar guru menunjukkan skor rata-rata 3,4 yang berkategorikan baik.

Dengan demikian dapat disimpulkan bahwa aktivitas belajar siswa dan aktivitas mengajar guru selama proses pembelajaran pada siklus I dan siklus II mengalami peningkatan. Dengan data ini, dapat dikatakan bahwa dengan memanfaatkan peta sebagai media pembelajaran dapat meningkatkan kualitas proses pembelajaran pada materi pengetahuan dasar pemetaan siswa kelas X IPS-2 SMAN 1 Wangi-Wangi. Hal ini sesuai dengan pendapat Asyad (2011) bahwa salah satu manfaat media pembelajaran adalah dapat memperjelas penyajian pesan dan informasi sehingga dapat memperlancar dan meningtakan proses dan hasil belajar.

\section{Hasil Belajar Siswa}


Berdasarkan hasil analisis kuantitatif yang dilakukan terhadap hasil belajar siswa dari siklus I sampai dengan siklus II cenderung mengalami peningkatan ke arah yang lebih baik.

Pada siklus 1, berdasarkan hasil tes belajar siswa diperoleh nilai rata-rata hasil belajar sebesar 74, dengan minimum 47 dan nilai maksimum 93. Secara klasikal dari 32 siswa yang mencapai peresentase ketuntasan hasil belajar yaitu 19 siswa atau 59\% dengan $\geq 70$ sesuai KKM geografi yang ditentukan sekolah dan terdapat 13 siswa dengan persentase $41 \%$ yang nilainya belum mencapai KKM. Data ini menunjukkan bahwa persentase ketuntasan pada siklus 1 belum mencapai target peneliti yaitu minimal 80\% ketuntasan klasikal.

Setelah melakukan analisis dan refleksi hasil belajar siklus I, dicoba melakukan upaya perbaikan oleh guru dalam proses belajar mengajar agar pada siklus II siswa yang memenuhi kriteria ketuntasan hasil belajar dapat meningkat. Pada siklus II, berdasarkan hasil tes belajar siswa terlihat bahwa terjadi peningkatan nilai rata-rata hasi belajar siswa menjadi 79 dengan nilai minimum 40 dan nilai maksimum 100. Secara klasikal ketuntasan hasil belajar mencapai target yang diharapkan yaitu $81 \%$ dimana, terdapat 26 siswa yang tuntas mencapai nilai KKM $\geq$ 70 dan 6 siswa yang tidak tuntas

dengan persentase $19 \%$ karena memperoleh nilai yang tidak memenuhi $\mathrm{KKM} \leq 70$.

Pada siklus II target ketuntasan hasil belajar telah tercapai karena terdapat $81 \%$ siswa yang tuntas hasil belajarnya. Keadaan ini menunjukkan bahwa peneliti telah berhasil mencapai terget. Dalam penelitian ini keberhasilan belajar siswa dalam tes belajar dijadikan sebagai indikator atau tolak ukur yang memberikan gambaran bahwa penggunaan media peta mampu meningkatkan hasil belajar. Dari siklus I dan siklus terjadi peningkatan hasil belajar sebesar $22 \%$. Dengan

demikian, dari uraian tersebut dapat disimpulkan bahwa jawaban atas permasalahan penelitian telah terungkap dan itu artinya bahwa dengan pemanfaataan peta pada materi pengetahuan dasar pemetaan dapat meningkatkan kualitas aktivitas belajar siswa dan dapat meningkatkan hasil belajar.

Sesuai dengan hasil penelitian sebelumnya yang dilakukan oleh Khoirul (2013) Pengaruh Media Peta Rupa Bumi Dalam Pembelajaran Geografi Terhadap Hasil Belajar Siswa Kelas XII IPS SMA Islam An-Nidhom Kabupaten Demak Tahun Ajaran 2012/2013. Penggunaan media peta rupa bumi dalam pembelajaran geografi siswa kelas XII IPS Islam An-Nidhom mengalami peningkatan. Hal ini dapat dilihat berdasarkan (1) kognitif kelas eksperimen 73,33 dan kelas kontrol 67.47, (2) afektif kelas eksperimen dan kontrol sama mengalami kenaikan belajar, (3) psikomotorik kelas eksperimen 83,57 dan kelas kontrol 69,30.

\section{KESIMPULAN}

Berdasarkan hasil penelitian dapat ditarik beberapa kesimpulan sebagai berikut :

1. Aktivitas siswa dengan memanfaatkan peta sebagai media pembelajaran pada siklus I dan siklus II mengalami peningkatan.

2. Aktivitas guru saat mengajar dengan memanfaatkan peta sebagai media pembelajaran pada siklus I dan sikluS II mengalami peningkatan. 
3. Hasil belajar geografi siswa kelas X IPS-2 SMAN 1 Wangi-Wangi meningkat $22 \%$ dari siklus I sebesar $59 \%$ dan meningkat $81 \%$ pada siklus II setelah menggunakan media peta pada materi pengatahuan dasar pemetaan.

\section{DAFTAR RUJUKAN}

Arsyad, Azhar. 2011. Media Pembelajaran. Jakarta: PT. Raja Grafindo Persada.

BSNP. 2006. Kurikulum Tingkat Satuan Pendidikan (KTSP). Jakarta: Permendiknas RI.

Hamalik, Oemar 2006. Proses Belajar Mengajar. Bandung: Bumi Aksara.

Khoirul. Pengaruh Media Peta Rupa Bumi Dalam Pembelajaran Geografi Terhadap Hasil Belajar Siswa Kelas XII IPS SMA Islam An-Nidhom Kabupaten Demak Tahun Ajaran 2012/2013. Semarang: Fakultas Ilmu Sosial. Universitas Negeri Semarang.

Mulyasa. 2003. Manajemen Berbasis Sekolah. Bandung: Remaja Rosdakarya.

Prasetya Sukma Perdana. 2015. Media Pembelajaran Geografi. Yogyakarta: Ombak.

Soedibyo, Lies. 2011. Peranan dan Dampak Teknologi Informasi dalam Dunia Pendidikan. Sukoharjo.

Sudiharjo, Basuki. 1986. Peta, Sejarah, dan Kegunaannya. Pidato Pengukuhan Guru Besar. Yogyakarta: Fakultas Geografi, UGM.

Sudjana. 2002. Metode Statistika. Bandung: Tarsito.

Usman, Moh. Uzer dan Lilis Setiawati. 2001. Upaya Optimalisasi Kegiatan Belajar Mengajar. Bandung: Remaja Rosdakarya

\section{Editor In Chief}

\section{Erman Syarif}

emankgiman@unm.ac.id

\section{Publisher}

\section{Geography Education, Geography Departemenr, Universitas Negeri Makassar}

Ruang Publikasi Lt.1 Jurusan Geografi Kampus UNM Parangtambung, Jalan Daeng Tata, Makassar.

Email: lageografia@unm.ac.id

Info Berlangganan Jurnal 085298749260 / Alief Saputro 